\title{
Grizzlies, dodos and Gore put science on film
}

\section{WASHINGTON DC}

Al Gore, the former US vice-president who lost his fight for the presidency to George W. Bush in 2000, is starring in a new documentary that features his presentations on climate change. The film is just one of several sciencerelated documentaries hitting the big screen this year.

The environment has long interested Gore, who published a book on the threat of climate change, Earth in the Balance, in 1992. More recently he has been touring the United States with a slide-show presentation on the dangers that his scientist supporters say is scientifically accurate and compelling. "He's very effective and right on target, and I've never seen better visuals," says Eric Chivian, director of the Center for Health and the Global Environment at Harvard Medical School in Boston, who helped Gore with sections on the effects of global warming on polar bears.

Michael Oppenheimer, a geoscientist and environmental-policy expert at Princeton University, agrees. "I have talked to thousands of politicians and very few of them have been willing to do the homework and get down to the details," he says. "When Al Gore gets revved up, he is very impressive."

But it wasn't until Gore's slide-show was made into a feature-length documentary, first screened at the Sundance film festival in Utah last month, that his efforts started making headlines around the world. An Inconvenient Truth was directed by Davis Guggenheim and produced by Participant Productions, a film company set up in 2004 with an explicitly activist agenda. The company's other films include Syriana and Good Night and Good Luck, which deal with the global oil industry and the freedom of the

"Scientists have neglected the communication skills needed to engage with mass audiences." press, respectively.

Last week, Participant Productions secured a distribution deal with Paramount Pictures that should see An Inconvenient Truth get a US release in May. Supporters hope that the film will not only revive Gore's political career but will take his climate message to a wider audience than his original slide-show could ever have reached.

Thom Powers, a documentary producer who heads the documentary film programme at the Toronto International Film Festival, says that both science and political documentaries are becoming much more popular. "March of the Penguins was I think the second-highest grossing documentary of all time, second only

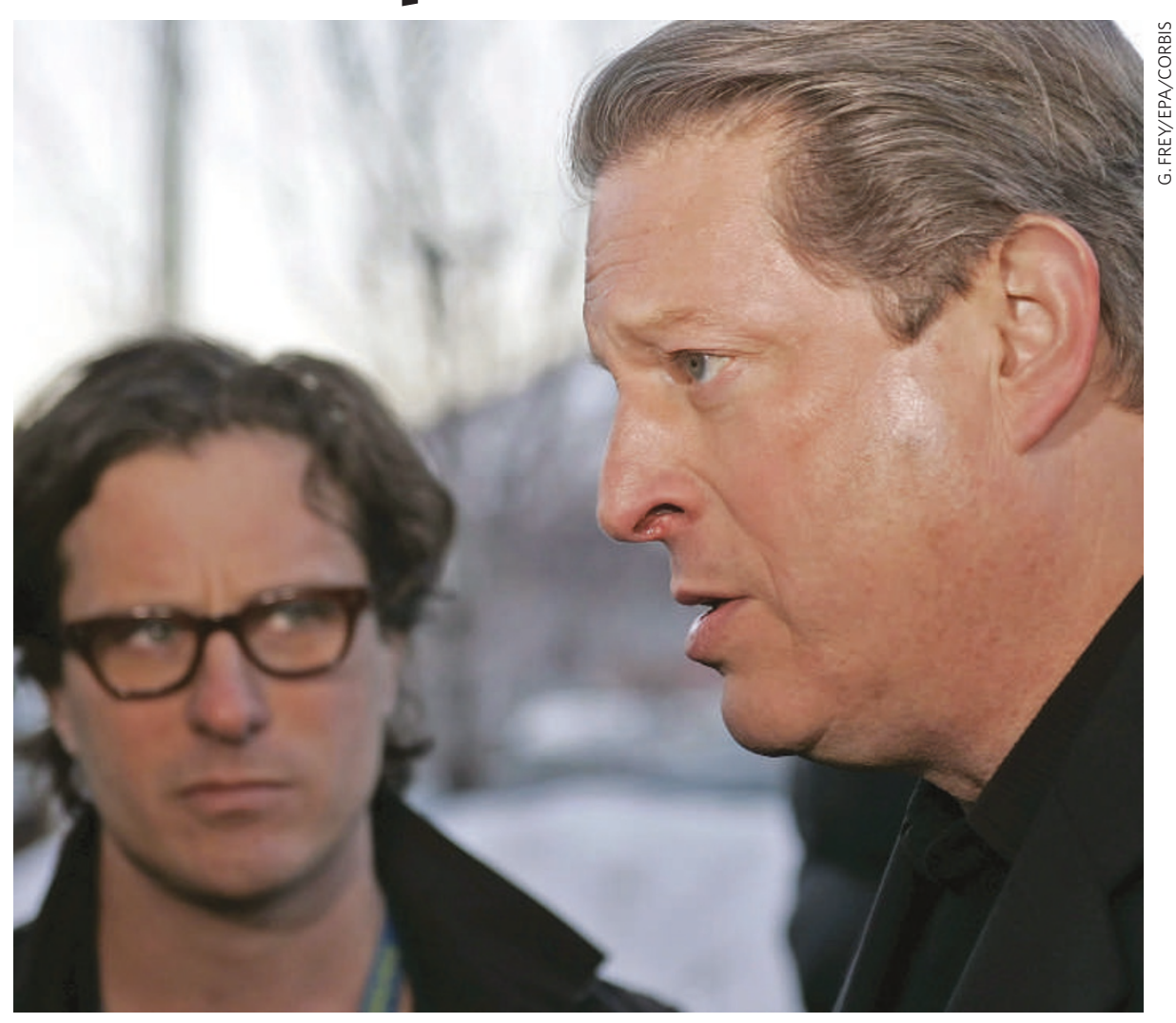

Al Gore (right) promotes his film on climate change while director Davis Guggenheim looks on.

to Michael Moore’s Farenheit 9/11," he says. "Al Gore's documentary has a nice confluence of a couple of different interest areas: growing viability of political documentaries, and interest in the environment."

The trend is growing. Moore, who helped get documentaries into movie theatres with his hit films Bowling for Columbine, about gun control in the United States, and Farenheit 9/11, about the Bush administration's actions in the wake of the terrorist attacks of 11 September 2001, is now working on a film about the pharmaceutical industry, called Sicko. And one of the year's most talked about films is Werner Herzog's Grizzly Man, a portrait of a man who lived among - and was eventually eaten by - Alaska's grizzly bears and claimed to be protecting them, although government experts say the population is doing well.

Doron Weber, who runs the Public Understanding of Science and Technology programme at the Alfred P. Sloan Foundation in New York, gave an award to Herzog's film. He says that boom times for documentaries are good for showing the subtleties of science. "A film like Grizzly Man presents a character in the round and presents conflicting ideas," he says. "Film is such a good medium for this."

Another director taking advantage of the medium is Randy Olson. His film Flock of Dodos, about the clashes between evolutionary scientists and advocates of intelligent design, had its first screening in Kansas earlier this month. Olson comes down on the side of evolution, but sends a message that scientists have neglected the communication skills needed to engage with mass audiences, and failed to compete with the public-relations operations of advocates of intelligent design. "Science has backed into this lumbering, conservative corner, with no flexibility to deal with something like intelligent design when it comes up," says Olson.

Chivian says the same of the climate-change debate: "What really worries me is that scientists haven't done a great job of communicating these issues. We are trained to talk in technical language to each other." Many hope that the new wave of science documentaries will help to change that.

Emma Marris

Additional reporting by Kendall Powell. 